\title{
ENRICHMENT OF MEASLES VIRUS-LIKE RNA IN THE NUCLEOCAPSID FRACTION ISOLATED FROM SUBACUTE SCLEROSING PANENCEPHALITIS BRAINS
}

\author{
ELLIOTT BEDOWS ${ }^{1}$, DAVID E. KOHNE ${ }^{2}$, WALLACE $W$. TOURTELLOTTE $^{3}$ and FRANCIS E. \\ PAYNE ${ }^{4, *}$ \\ 'Departments of Epidemiology and Anaesthesiology, School of Public Health and School of Medicine, \\ University of Michigan, Ann Arbor, MI 48109; ${ }^{2}$ Center for Neurologic Study, 11575 Sorrento Valley \\ Road, Suite 203, San Diego, CA 92121; ${ }^{3}$ Chief, Neurology Service, V.A. Wadsworth Hospital Center, \\ Wilshire and Sawtelle Boulevards, Los Angeles, CA 90073; and " Professor of Epidemiology, School \\ of Public Health, University of Michigan, Ann Arbor, MI 48109, U.S.A.
}

(Accepted 20 October 1981)

A procedure has been developed which facilitates the detection of measles virus RNA sequences in human brains. The procedure involves isolating subviral components (nucleocapsids) from brain tissues prior to RNA purification, followed by hybridization of these RNAs to cDNA synthesized from measles virus $50 \mathrm{~S}$ RNA template. Using these techniques we were able to obtain an RNA fraction which was manyfold enriched in measles virus-specific RNA, relative to unfractionated subacute sclerosing panencephalitis (SSPE) brain RNAs. 70-100\% of the measles virus-specific RNA present in these SSPE brain samples were recovered in this enriched fraction.

brain tissue measles virus nucleocapsid isolation subacute sclerosing panencephalitis (SSPE) RNA enrichment virus RNA

\section{INTRODUCTION}

Measles virus causes an acute infection in humans and has been implicated as the etiologic agent in a number of progressive diseases. Viruses which appear to be variants of classical measles virus have been isolated from the brains of patients with subacute sclerosing panencephalitis (SSPE) (Payne and Baublis, 1971). Measles virus has also been implicated as a possible agent in other diseases including multiple sclerosis and systemic lupus erythematosus (for a review, see Morgan and Rapp, 1977).

The cultivation of viruses from diseased tissue is difficult, time-consuming and often impossible. One cannot always be certain that autopsy specimens have been collected in such a way as to minimize the breakdown of intracellular components, including viruses. In the time between death and tissue collection considerable nucleolytic and proteolytic damage may occur.

* Deceased. 
The use of high-specific radioactivity nucleic acids as viral probes provides the capability of assaying a tissue for virus, even though virus cannot be grown because it is defective or has been damaged. However, unlike the situation which occurs with virusinfected cells in culture, only a small portion of the brain cells may contain virus particles. This can make the virus nucleic acid more difficult to detect, since the virus-like nucleic acid will be very dilute. Here we describe a technique for the preferential enrichment of measles virus-like RNA from SSPE brains.

\section{RESULTS AND DISCUSSION}

It is generally thought that measles virus RNA is very stable when in its encapsidated intracellular state. Fig. 1 shows the sedimentation profiles of $\left[{ }^{3} \mathrm{H}\right] \mathrm{RNA}$ purified from measles virus nucleocapsids which were incubated in a clarified SSPE brain lysate as described in the legend. The incubation of the $\left[{ }^{3} \mathrm{H}\right]$ uridine-labeled nucleocapsids in the clarified lysate
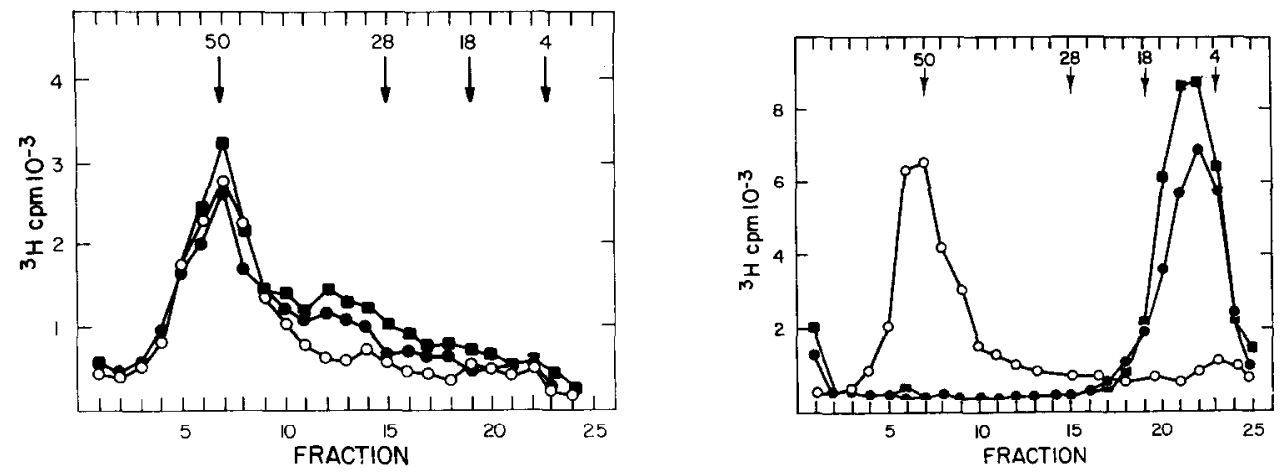

Fig. 1. Effect of nucleocapsid pelleting procedure on RNA degradation. Approximately $2 \mathrm{~g}$ of a frozen brain section containing approximately equal amounts of gray and white matter, was diluted $1: 5(\mathrm{w} / \mathrm{v})$ in phosphate-buffered saline $(\mathrm{pH} 7.5)$ and homogenized at medium speed in a Vertis homogenizer. The cellular debris was pelleted for $10 \mathrm{~min}$ at $1000 \times \mathrm{g}$, and the supernatant decanted. $\left[{ }^{3} \mathrm{H}\right]$ Uridine-labeled measles virus nucleocapsids purified as described previously (Kiley et al., 1974) were then added to either $1 \mathrm{ml}$ of NTE $(100 \mathrm{mM} \mathrm{NaCl}, 25 \mathrm{mM}$ Tris pH 7.8, $1 \mathrm{mM}$ EDTA) buffer $(0)$, or to brain extract which was then allowed to incubate for zero (•) or $21 \mathrm{~h} \mathrm{(-)}$ at $22^{\circ} \mathrm{C}$. The nucleocapsid fraction was then isolated from each sample by centrifugation through NTE buffer containing $15 \%(\mathrm{w} / \mathrm{v})$ sucrose at $100000 \times \mathrm{g}$ for $4 \mathrm{~h}$. The resulting pellet was resuspended in $1 \mathrm{ml}$ NTE buffer, incubated $\left(30 \mathrm{~min}\right.$ at $\left.65^{\circ} \mathrm{C}, \mathrm{pH} 8.3\right)$ with proteinase $\mathrm{K}(100 \mu \mathrm{g} / \mathrm{ml})$ and $1 \% \mathrm{SDS}$, and then extracted with phenol-chloroform to purify the RNA. The RNAs were layered on to a $15-30 \%$ $(w / v)$ sucrose gradient and centrifuged for $11 \mathrm{~h}$ at $100000 \times g$ in order to determine the sedimentation profiles of the different RNAs shown above. Sedimentation is from right to left with ${ }^{3} \mathrm{H}$-labeled Vero cell RNA and measles virus RNA serving as markers.

Fig. 2. Effect of phenol extraction purification procedure on RNA degradation. Purified ${ }^{3} \mathrm{H}$-labeled measles virus nucleocapsid material was added to brain lysate and RNA purified as described in Fig. 1, except that the nucleocapsid-pelleting step was omitted. Shown are the RNA profiles for nucleocapsids incubated in buffer (o) or in cell lysate for $1(\bullet)$ or $24(-) \mathrm{h}$. 
did not result in extensive breakdown of the added $\left[{ }^{3} \mathrm{H}\right]$ uridine-labeled nucleocapsid RNA. It was observed that the measles virus genomic RNA was degraded substantially if the nucleocapsid purification step was omitted (Fig. 2). Still, the degraded material in Fig. 2. was $>85 \%$ acid precipitable and large enough to hybridize (Table 1). It is interesting that the size of the measles virus RNA recovered is the same whether nucleocapsids are incubated in brain lysate for 1 or $24 \mathrm{~h}$. This indicates that nucleolytic digestion occurs during the extraction procedure itself, and that the measles virus RNA is quite stable as long as it is within its protein coat. When measles virus mRNA was added to the SSPE- 1 brain lysate, it was rapidly degraded. Less than $5 \%$ of the material was acid precipitable after $15 \mathrm{~min}$ of incubation at $20^{\circ} \mathrm{C}$.

Considerable RNA degradation was observed in all other lysates prepared from either

\section{TABLE 1}

Hybridization of measles $\left[{ }^{3} \mathrm{H}\right] \mathrm{cDNA}$ with various nucleic acids

\begin{tabular}{lcccc}
\hline & RNA or DNA & $\begin{array}{l}\text { Total } \\
C_{0} t\end{array}$ & $\begin{array}{l}\%\left[{ }^{3} \mathrm{H}\right] \mathrm{cDNA} \\
\text { adsorbed to HA }\end{array}$ & $\begin{array}{c}\text { Hybridization } \\
C_{0} t_{1 / 2}\left(\mathrm{~ms} \cdot 1^{-1}\right)\end{array}$ \\
\cline { 2 - 5 } & 300 & 0.75 & 56 & 0.05 \\
$\begin{array}{l}\text { Measles 50 S RNA } \\
\text { Measles-infected } \\
\text { Vero cell RNA }\end{array}$ & $9 \times 10^{5}$ & 513 & 58 & 13.5 \\
$\begin{array}{l}\text { SSPE-1 brain } \\
\text { cell debris RNA } \\
\text { (fraction A) }\end{array}$ & $1.5 \times 10^{7}$ & 195 & 54 & 160 \\
$\begin{array}{l}\text { SSPE-1 brain } \\
\text { nucleocapsid RNA } \\
\text { (fraction B) }\end{array}$ & $6.4 \times 10^{3}$ & 6.4 & 60 & 0.42 \\
$\begin{array}{l}\text { Unfractionated SSPE-1 } \\
\text { brain RNA }\end{array}$ & $2.9 \times 10^{\circ}$ & 780 & 54 & 39 \\
$\begin{array}{l}\text { Uninfected } \\
\text { Cell RNA } \\
\text { Vero }\end{array}$ & $6 \times 10^{4}$ & 120 & 1.0 & - \\
$\begin{array}{l}\text { Fetal human } \\
\text { liver DNA }\end{array}$ & $8 \times 10^{\circ}$ & 2312 & 1.5 & - \\
\hline
\end{tabular}

Hybridization assays were performed by the method of Kohne and Britten (1971) as follows. RNAs extracted from a section of the brain of an SSPE patient were extracted as described in the text and incubated at $3-100 \mu \mathrm{g} / \mathrm{ml}$ (nucleocapsid-containing fractions) or at $2-4 \mathrm{mg} / \mathrm{ml}$ (total RNA-containing) for $1-50 \mathrm{~h}$ at $65^{\circ} \mathrm{C}$ in $0.48 \mathrm{M}$ phosphate buffer (PB) in the presence of 6-12 pg (300-600 c.p.m.) CDNA probe. At various $C_{0} t$ values an aliquot of the reaction mixture was passed over a hydroxy apatite (HA) column equilibrated to $62^{\circ} \mathrm{C}$ in $0.14 \mathrm{M}$ PB. Hybridized material which adhered to the column under these conditions was eluted with $0.48 \mathrm{M} \mathrm{PB}$ and the percentage of counts sticking to the column determined. Numerous points were taken for each sample. Shown above are the $C_{0} t / 2$ values for the kinetic reactions, the ultimate hybridization plateau level, the ratio of probe to test nucleic acid for each reaction mixture, and the total $C_{0} t$ for indicated reactions. Less than $2 \%$ selfreaction of the $\left[{ }^{3} \mathrm{H}\right] \mathrm{cDNA}$ occurred. 
SSPE or control brains. Since our probe does not react with rRNA (Table 1), and since our extraction procedure disrupts all polysomes which might endure (Kiley et al., 1974), it must be assumed that all material reacting with our measles virus-specific probe is nucleocapsid RNA and is most likely in nucleocapsid protein since free RNA is degraded so rapidly. These experiments indicate that any nucleocapsid particles naturally present in SSPE brain might also be intact and possible to isolate. Therefore, brain tissue was processed and the nucleocapsid fraction obtained from five SSPE brains and a number of controls as described below.

The nucleocapsid fraction was isolated from Vertis-homogenized brain tissue as described in Fig. 1, except that the supernatant fractions of cell lysates were layered on $15 \%$ sucrose (rather than a 15-30\% sucrose gradient) and the nucleocapsid-containing extracts centrifuged for $4 \mathrm{~h}$ (rather than $3 \mathrm{~h}$ ) to pellet nucleocapsid material. Three different fractions resulted: A) the cellular debris pellet obtained in the initial clarification centrifugation of the Vertis-homogenized brain (see Fig. 1); B) the pellet obtained from ultracentrifugation of the initial, clarified supernatant (if present the nucleocapsids will be in this fraction); and $\mathrm{C}$ ) the supernatant from the ultracentrifugation step. The RNA was isolated for each fraction.

Unfractionated RNA was also isolated from a separate sample of brain by thawing an identical piece of tissue in $3.2 \mathrm{M}$ sodium trichloroacetic acid $(\mathrm{pH} \mathrm{7.0)}$ and purifying the nucleic acids by phenol-chloroform extraction and ethanol precipitation. This nucleic acid-containing pellet was then incubated in NTE buffer ( $\mathrm{pH} \mathrm{8.3)} \mathrm{containing} 100 \mu \mathrm{g} / \mathrm{ml}$ proteinase $\mathrm{K}$ and $1 \% \mathrm{SDS}$ for $30 \mathrm{~min}$ at $65^{\circ} \mathrm{C}$, re-extracted with phenol-chloroform and ethanol precipitated again. The concentration of measles virus-like RNA in each RNA preparation was then determined by nucleic acid hybridization kinetics (Britten and Kohne, 1968), using high specific radioactivity $\left(2 \times 10^{8} \mathrm{dpm} / \mu \mathrm{g}\right)\left[{ }^{3} \mathrm{H}\right] \mathrm{cDNA}$ synthesized by using measles virus $50 \mathrm{~S}$ RNA as a template (Taylor et al., 1976) (Table 1).

The measles virus $50 \mathrm{~S}$ RNA used as template for the production of the cDNA was about 60-70\% double-stranded after self-hybridization. Spruance et al. (1980) and Bedows and Payne (1981) have also observed that a large fraction of $50 \mathrm{~S}$ measles virus nucleocapsid RNA is composed of plus and minus strands. The 50 S RNA was denatured before being used as a template for cDNA. Table 1 summarizes the hybridization characteristics of the $\left[{ }^{3} \mathrm{H}\right] \mathrm{cDNA}$. The maximum extent of hybridization of the cDNA is about $60 \%$. This incomplete reaction is probably due to the presence of plus and minus measles virus RNA in the $50 \mathrm{~S}$ and measles virus-infected cell RNA.

Table 1 compares the hybridization of our measles virus cDNA to various RNA fractions of one of the SSPE brains (SSPE-1). The bulk of the RNA from the SSPE-1 brain tissue sample was present in fraction A (675 $\mu \mathrm{g} \mathrm{RNA} / \mathrm{g}$ tissue). Fraction B, the nucleocapsid fraction, contained about 100 times less RNA $(6.2 \mu \mathrm{g} / \mathrm{g}$ tissue). Less than $1 \mu \mathrm{g}$ of RNA/g tissue was found in fraction $\mathrm{C}$.

The concentration of measles virus RNA in the A, B, and unfractionated RNA preparations was determined by nucleic acid hybridization kinetic studies. The kinetics of hybridization of measles virus $\left[{ }^{3} \mathrm{H}\right] \mathrm{cDNA}$ plus the various RNA preparations yielded 
$C_{0} t_{1 / 2}$ values of hybridization of $0.42 \mathrm{~ms} \cdot \mathrm{l}^{-1}$ for RNA B, $160 \mathrm{~ms} \cdot \mathrm{1}^{-1}$ for RNA A, and $39 \mathrm{~ms} \cdot 1^{-1}$ for unfractionated RNA. Thus, the nucleocapsid RNA fraction had a measles virus RNA concentration 93 times higher than the unfractionated SSPE brain RNA. This indicates that the nucleocapsid isolation procedure resulted in a great preferential enrichment of measles virus-specific RNA.

Comparison of measles virus RNA recovered from the unfractionated RNA preparation and the nucleocapsid-like pellet indicated that at least $75 \%$ of the measles virus sequences in the SSPE-1 brain were recovered in fraction B RNA. Furthermore, in most other SSPE brains examined, an even greater recovery was observed (Table 2). The kinetics of reaction of $\left[{ }^{3} \mathrm{H}\right] \mathrm{cDNA}$ with unfractionated SSPE-1 RNA also provided information as to the frequency of occurrence of the measles virus-specific RNA molecules in SSPE brain cells. On the average, each SSPE- 1 brain cell from this patient contained about 400-600 measles virus RNA molecules (the RNA/DNA ratio of brain cells is about 1:1). Measles virus-infected Vero cells contained around 1000-2000 measles virus RNA copies per cell on an average (the RNA/DNA ratio of these cells is 2-3:1).

The $T_{\mathrm{m}}$ values of measles virus cDNA : SSPE-1 RNA hybrids and measles virus cDNA : measles virus-infected cell RNA hyb rids were also measured in $0.14 \mathrm{M}$ phosphate buffer (PB) and found to be $79^{\circ} \mathrm{C}$ and $83^{\circ} \mathrm{C}$ respectively. These data are consistent with the high extent of reaction seen for measles virus $\left[{ }^{3} \mathrm{H}\right] \mathrm{cDNA}$ and this SSPE RNA (close to $100 \%$ when normalized, see Table 1) and indicate that about 4-6\% nucleotide sequence difference exists between SSPE virus and the Edmundston measles virus strain. These data are consistent with, and expand somewhat, the data of Hall and Ter Meulen (1976).

Table 2 compares the hybridization reactions between five SSPE brains. (Three identically prepared control brains were also assayed but failed to hybridize $(<1 \%)$ to the probe.) Three of five SSPE brain RNAs tested hybridized an equivalent amount of cDNA probe as measles virus-infected Vero cell RNA. It is possible that the failure of these other RNAs to hybridize reflects the presence of a high level of competing positivestranded material. Alternatively, these brains may exclusively contain measles virus nucleocapsid particles of a highly fragmented nature representing only a small portion of the measles virus genome.

Comparison of the reaction rates of nucleocapsid RNA vs. total RNA indicates that in all cases except SSPE-3, there is a 100-3000-fold concentration in measles virus-specific sequences from those SSPE brains. The large disparity between these values may reflect a difference in nuclease levels between brains which could rapidly diminish total RNA concentrations.

Although only 1-3\% as much RNA is extracted by the nucleocapsid pelleting technique as by total RNA extraction, the vast majority of measles virus sequences were recovered during the nucleocapsid pelleting technique (Table 2). Thus the ability to concentrate a specific virus RNA by isolating its nucleocapsid fraction has great potential usefulness. 'The higher concentration of viral nucleic acid or nucleocapsid protein greatly increases the sensitivity of detection of these sequences when assayed by nucleic acid 


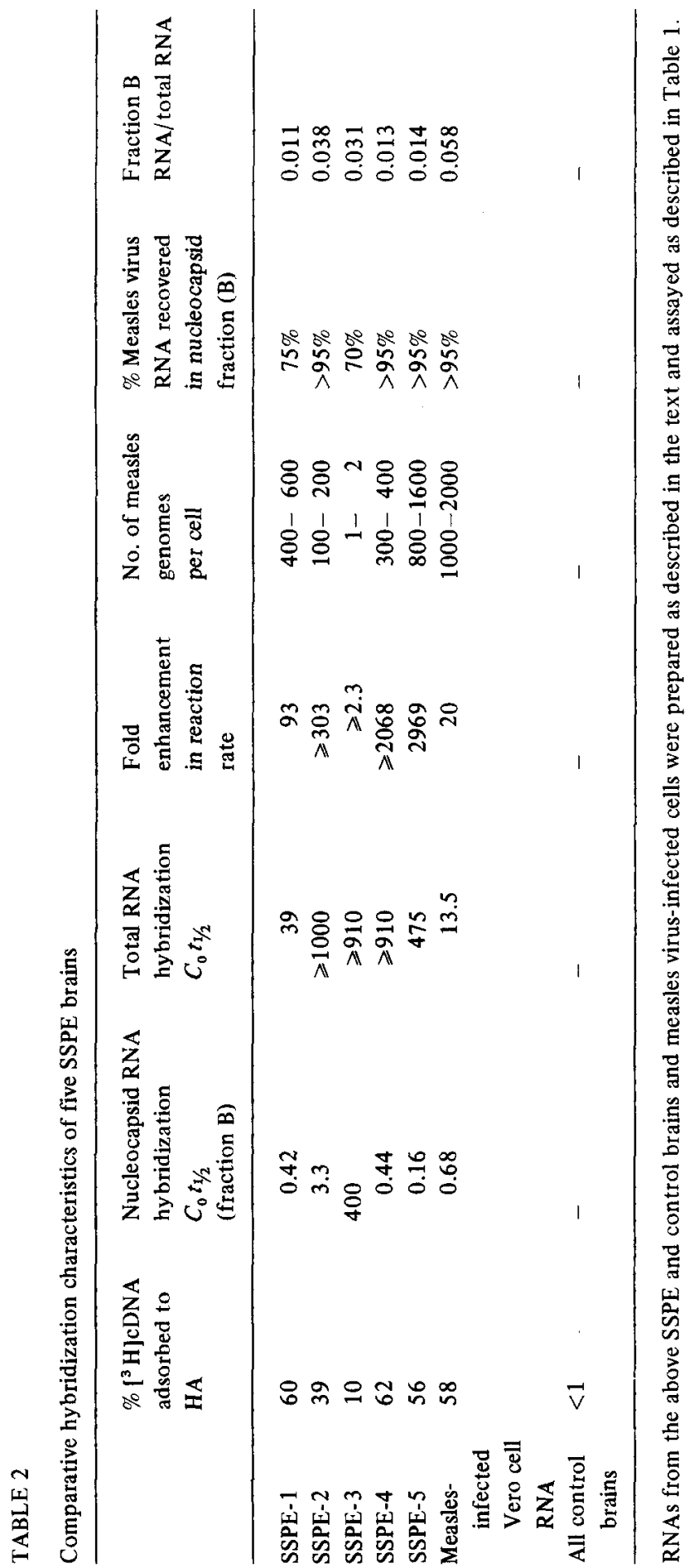


hybridization or by immunologic methods, thus increasing the chance of detecting the virus if it is present at low levels. While it is clear that this approach will not work for every virus species, it is hoped that it will prove useful in determining whether diseases such as multiple sclerosis have a measles virus etiology.

\section{ACKNOWLEDGEMENT}

This work was supported in part by PHS grants NS 09547 and NS 16311 awarded by the National Institute of Ncurologic and Communicative Disorders and Stroke and by grant RG 787-D-5 from the National Multiple Sclerosis Society.

\section{REFERENCES}

Bedows, E. and F.E. Payne, 1981, J. Virol. 37, 103.

Britten, R.J. and D.E. Kohne, 1968, Science 161, 529.

Hall, W.W. and S.J. Martin, 1973, J. Gen. Virol. 19, 175.

Hall, W.W. and V. ter Meulen, 1976, Nature (London) 264, 474.

Kiley, M.P., R.H. Gray and F.E. Payne, 1974, J. Virol. 13, 721.

Kohne, D.E. and R.J. Britten, 1971, in: Procedures in Nucleic Acid Research, Vol. 2, eds. G. Cantoni and D. Davies (Harper and Row, New York, London) p. 500.

Morgan, E.M. and F. Rapp, 1977, Bacteriol. Rev. 41, 636.

Payne, F.E. and J.V. Baublis, 1971, Perspect. Virol. 7, 179.

Spruance, S.L., B.N. Ashton and C.B. Smith, 1980, J. Virol. Methods 1, 223.

Taylor, J.M., R. Illmensee and J. Summer, 1976, Biochim. Biophys. Acta 442, 324. 